\title{
Chapter 23: \\ The conflict between privatisation and the realisation of the right to water in Kenya
}

\author{
Nerima Akinyi Were
}

In 2009, figures released by the World Bank indicated that there was an estimated $42 \%-59 \%$ of nationally piped water coverage in Kenya. ${ }^{1}$ These figures, which remain the most recent estimates, are supported by Water Sector Strategic Plan ${ }^{2}$, which indicates that water coverage in rural areas is estimated at $40 \%$ and in urban areas at $60 \%$. These figures show that millions of Kenyans have inadequate water supply. ${ }^{3}$ Within urban areas, informal settlements have proven difficult to reach in terms of water supply and in rural areas women and girls are most affected, as they have to spend disproportionate amounts of time and travel long distances to fetch water at the expense of other activities including school. ${ }^{4} 2010$ figures comparing poor and non-poor households in Kenya's major cities (Nairobi, Mombasa and Kisumu) revealed that a minimum of $30 \%$ of poor households were forced to rely on small-scale water providers ${ }^{5}$ for water, while a maximum of $32 \%$ of non-poor households were in the same position. ${ }^{6}$ There is also significant water deprivation with $57 \%$ of low-income households surveyed consuming less than the water poverty line of 20 litres per capita per day and about $62 \%$ of households spending above their affordability threshold on water. ${ }^{7}$

The inadequacy of water access in Kenya goes beyond the government's laxity in water provision. The major cities are poorly planned and populations exceed the capacity of the cities. Even with this consideration in mind, one must note the fairly low estimates of piped water coverage. However, piped water is not the only source of water. In August 2011, the Guardian ${ }^{8}$ reported that, in 2007, the Water and Sanitation

1 Uwazi InfoShop (undated).

2 Government of Kenya (2010).

3 Water and Sanitation Programme (undated: 8); and Government of Kenya (2009).

4 Government of Kenya (2010).

5 There are different types of small scale water providers these are tap water vendors, water kiosks (a kiosk is a small usually makeshift shop), borehole water vendors, pushcart vendors and tanker trucks.

$6 \quad$ Uwazi InfoShop (undated).

$7 \operatorname{UNDP}(2011)$.

8 Mugo (2011). 
for the Urban Poor Project began to implement a project to help nearly 100,000 poor peri-urban dwellers in Naivasha access portable, affordable, accessible and reliable drinking water. This project resulted in certain consumers reliant on kiosks paying Ksh. 50 per cubic meter of water, a Ksh. 200 reduction from previous prices. An encouraging drop at the time but an indictment to the plight of many people because the cost of water remains high in a country where more than $58 \%$ of the population lives on less than 2 dollars (USD) per day.

However, it is encouraging to note that there have been significant investments in water resource management and water services. The state, through the Ministry of Water, almost tripled the budget spent on water infrastructure from Kshs.6.9 billion in $2004 / 2005$ to Kshs. 18.6 billion in $2008 / 2009 .{ }^{9}$

This chapter explores the privatisation of water in Kenya and begins by defining privatisation and contextualising it in Kenya. Privatisation has been defined as: ${ }^{10}$

\section{the entire process of expanding the sphere of the market through a host of regulations that create an enabling environment for free enterprise to operate as a strategy for sustainable economic development.}

Kenya's water policy after independence was founded on the country's landmark postcolonial nation-building and socio-economic development blueprint, Sessional Paper No. 10 on African Socialism and its Application to Kenya (1965), which emphasised political equality, social justice and human dignity. ${ }^{11}$ Its principles were grounded on state control of the economy, defining the state as the entity that implements social and economic programmes to address historical and social inequalities. The logical consequence of this was that the government delivered basic services including water and health at no cost and other actors were minimally involved in service delivery. ${ }^{12}$

While alleviating poverty through the provision of safe drinking water formed part of the political agenda, the government's ambitious target to provide water freely for all was not realised. Water service provision coverage remained low in the years after independence. ${ }^{13}$ Issues identified to explain this shortfall included lack of cost-efficient recovery mechanisms and operation and maintenance systems, and the government's failure to renew existing systems leading to many becoming non-operational. ${ }^{14}$ In seeking to deal with these shortfalls, the responsibility for water service provision

9 Uwazi InfoShop (undated).

10 Moyo \& Kinuthia-Njenga (1998: 6).

11 Government of Kenya (1965).

12 Notley et al. (2010).

13 Ibid: 16.

14 Ibid. 
shifted from the state, and a call was made to individuals to take on the mandate to help themselves. This was followed initial by increased investment through donor funding and thereafter privatisation ensued.

The state's inability to deliver on Sessional Paper No. 10 became apparent with growing disillusionment among government actors from the mid-1970s and the early 1980s. ${ }^{15}$ The government used Harambee (the spirit of pooling resources together) as a vehicle for the country's social and economic development. ${ }^{16}$ Communities and individuals were encouraged to consider their role in service provision and urged to help themselves. ${ }^{17}$ Harambee was used to shift the control of water resources, including the implementation of development projects, to local communities with minimum input and control from the state. ${ }^{18}$ While the policy was well intended, it achieved little in the water sector due to limited financial resources, lack of skilled human resources and limited investment in new projects. ${ }^{19}$

The development of the National Water Master Plan in 1974 signalled a shift in the proposal for the development of water supply and sanitation, with the underlying goal of providing water for all by 2000. Development partners worked with the government to implement the plan, which resulted in water service coverage growing rapidly in many provinces as a result of large regional or provincial projects being supported by donor partners. ${ }^{20}$ While coverage rapidly increased, there were glaring weaknesses in the model. The most notable one was sustainability. The large projects were donor driven and had the dual effect of undermined the state's role in service provision, particularly at the local level. This reduced political buy-in and ownership of the projects within the government, which had deteriorated by the time their management was handed over and could therefore not meet the needs of the project. ${ }^{21}$

The decade between the mid-80s and the mid-90s marked a shift in the provision of water services in Kenya. Relying on the liberal state ideology, the World Bank and the International Monetary Fund strongly marketed the limitation and undesirability of the state's role in the provision of basic services and provided both loans and aid conditions to support a shift along these lines. ${ }^{22}$ The role of the state was continuously redefined with strong arguments for limitating the role of the state in service provision. The role of the state was to be facilitative and was relegated to the creation of an enabling environment for free market operations. ${ }^{23}$ Other services, such as healthcare, were also affected by the introduction of user fees for both inpatient and outpatient

15 Ibid.

16 Ogendi \& Ong'oa (2009: 186).

17 Notley et al. (2010).

18 Ogendi \& Ong'oa (2009: 186).

19 Swallow et al. (2003).

20 Notley et al. (2010: 16); and Mwega (2009).

21 Notley et al. (2010: 16).

22 Chuma \& Okungu (2011).

23 Jaglin (2002: 232); and Wambua (2004: 4-7). 
services at health facilities. Patients were required to subsidise healthcare service financing to address budgetary constraints within the government. ${ }^{24}$

Liberal policies were introduced through the Fourth Kenya National Development Plan (1979-1983), which made provision for greater reliance on markets and for improved efficiency of the public sector. ${ }^{25}$ Detailed policy reforms came with the Sessional Paper No. 1 on Economic Management for Renewed Growth. ${ }^{26}$ This set up the framework for liberalisation of markets by introducing cost sharing for public services; reducing human resources in public service through retrenchments; selling state firms (parastatals) and privatising some government functions; removing price and import controls that protected agricultural enterprise; and removing some government subsidies and budget allocations away from social programmes. ${ }^{27}$

In 1988, the National Water Conservation and Pipeline Corporation was established. ${ }^{28}$ Its primary objective was to commercialise water sector operations and achieve financial autonomy in water operations. In 1992, the state conducted a Delineation Study of the Water and Sanitation Sector in Kenya, which strongly recommended institutional reforms for the water sector, highlighting the inefficacies in the existing system, particularly the slow shift to business like operation, inefficient service production and the low-cost recovery within the sector. ${ }^{29}$

During the early 1990s, the political atmosphere in Kenya was stagnant, a trend that continued in varying degrees until the end of the Moi regime despite the developments and changes in policy and institutional arrangements. Notably, water and sanitation services in Kenya remained inadequate, and though coverage grew rapidly in the early 1990 s, it slowed as the decade progressed and came to a standstill. ${ }^{30}$ Coverage figures stayed level or even declined after this period. ${ }^{31}$

The Water Act (2002) is perhaps the first law to set a framework for both the privatisation and commodification of water coherently, and to set the legislative framework for the shift of water from a public good to a commodity. ${ }^{32}$ The Water Act (2002) separated the management of water resources, the supply of water and the provision of water services. ${ }^{33}$ The Water Resource Management Authority was established to regulate water resources, and the Water Services Regulatory Board was established to

24 Chuma \& Okungu (2011).

25 Government of Kenya (1979). See also K'Akumu \& Appida (2006: 317).

26 Government of Kenya (1986).

27 Ibid.

28 It was established under the State Corporations Act, Chapter 446 of the Laws of Kenya through Legal Notice No. 270 of 24 June 1988.

29 Government of Kenya (1992).

30 Notley et al. 2010: 19).

31 Ibid: 16. See also K'Akumu \& Appida (2006: 315).

32 Water Act No. 8 of 2002.

33 Shurie et al. (2017: 6). 
regulate the supply of water. ${ }^{34}$ Section 113(1) of the Water Act (2002) provided the legislative authority for the transfer of the management and operation of water services to the Water Services Boards, shifting water services to water service providers regulated by Water Services Boards.

While the framework of the Water Act (2002) provided the legislative environment for shifting water service provision from the state to private hands, Section 57(5)(d) of the Act highlighted the shift to commodification and commercialisation of water services. This Section provided the following requirement for licensees for water services:

...the application shall not be granted unless the Regulatory Board is satisfied that ... the applicant, or any water service provider by whom the functions authorized by the licence are to be performed will provide the water services authorized by the licence on a commercial basis and in accordance with sound business principles.

Licensing was thus required for the commercial provision of water, which had to be in accordance with sound business principles. Water was, as a consequence, to be treated as a commodity that had to be supplied in a profitable enterprise. The commodification and privatisation of water services illustrate the failure to treat water as a human right, particularly because in this instance, there is a legislative requirement to supply water on a commercial basis by non-state parties.

The Water Act (2016) ${ }^{35}$ replaced the Water Act (2002). It recognises that water is a human right and that every person in Kenya has the right to clean and safe water in adequate quantities and to reasonable standards of sanitation. ${ }^{36}$ The Water Act (2016), like its predecessor, separates the management of water resources from the supply of water services. It also takes cognisance of the devolution of water services in line with the provisions of the Constitution of Kenya (2010) which creates two levels of government: national and county governments. Under the Constitution, functions have been apportioned to both government levels and in the case of water; water services' provision is the function of county governments. ${ }^{37}$ Water resource management and trans-county issues, such as pollution and the protection of water resources, are functions of the national governments. ${ }^{38}$

The Water Act (2016) establishes Water Services Development Boards, which are mandated to provide water services as water service providers until the operation, and management of waterworks is transferred to county governments. ${ }^{39}$ Section 86(5)(e) of the Water Act (2016) almost mirrors Section 57(5)(e) of the Water Act (2002) and requires that water services be provided on a commercial basis in accordance with

\footnotetext{
34 Ibid.

35 Water Act No. 43 (2016).

36 Section 63 of the Water Act 2016.

37 Kameri-Mbote \& Kariuki (2015: 108).

38 Ibid.

39 Section $68(\mathrm{~b})$ of the Water Act (2016).
} 
sound business principles. Additionally, Section 88(a) requires an applicant seeking to be a Water Services Provider to provide evidence that water services shall be provided on a commercial basis. Another provision speaking to commercialisation is Section 96 of the Water Act (2016) that requires the prescribed area for water services provision shall not be less than the area required for commercial viability. The Act goes even further in Section 97:

Where it appears necessary to the Regulatory Board, for the purpose of securing a commercially viable water service, it may, by notice in the Gazette, order a joint provision of water services or a transfer of water service and vary the relevant licenses accordingly.

While the Water Act (2002) also required water to be provided on a commercial basis, this was only mentioned once in the Act. In the Water Act 2016, however, commercial viability is a running theme and seems to form one of the determinants for the provision of water services as it is emphasised throughout the Act and plays a more prominent role than it did in 2002. Further, and this is also a criticism of the Water Act (2002), commercial viability or commercial basis are not defined..$^{40}$ However, what is apparent is that the Water Services Regulatory Board, in terms of the Water Act (2016), is required to provide standards of commercial viability, which county governments are required to adhere to. ${ }^{41}$

There is a positive shift in the Water Act (2016) besides the concern with commercial viability as a worrying running theme. Section 94(1) of the Act states that: "Nothing in this Act shall deprive any person or community of water services on the grounds only that provision of such services is not commercially viable". The Act goes further and establishes a Water Services Sector Trust Fund, which has a number of objectives including the provision of conditional and unconditional grants to assist in the financing of the development and management of water services in marginalised areas. ${ }^{42}$

The Water Act (2016) specifically highlights rural areas, which have been historically disadvantaged on the provision of water services, and requires that county governments put in place measures to provide water services in rural areas not considered to be commercially viable. ${ }^{43}$ This may ameliorate the harsh impact of the focus on commercial viability. It is worth noting that one of the objectives of the Water Services Sector Trust Fund is to provide financing for the development of water services in rural areas and under-served poor urban areas. ${ }^{44}$

In a nutshell, the Water Act (2016) has shifted from the approach of its predecessor: firstly, by recognising that water is a human right; secondly by taking into account historic injustices in the provision of water services; thirdly by making provision for

40 K'Akumu (2004: 217).

41 Section 77(2) of the Water Act (2016).

42 Section 114 of the Water Act (2016).

43 Section 94(2) of the Water Act (2016).

44 Section 114(b) and (c) of the Water Act (2016). 
the devolution of water services; and finally, by promoting commercial viability as a basic requirement for the provision of water services.

\subsection{International framework for the right to water}

The human right to water and sanitation has gone through a process of evolution from implicit responsibility, to explicit obligation and to an independent right. ${ }^{45}$ While the right to water and sanitation is not explicitly mentioned in the International Covenant on Economic Social and Cultural Rights (ICESCR) ${ }^{46}$ it has been recognised by the Committee on Economic, Social and Cultural Rights (the Committee) through General Comment No. 15: The Right to Water (Articles 11 and 12 of the Covenant). ${ }^{47}$ The Committee relied on Articles 11 and 12 of the ICESCR on the right to adequate standard of living including adequate food, clothing and housing and the right to the highest attainable standard of health respectively. The Committee opines that the right to water is inextricably linked to these rights given that it is one of the most fundamental conditions for survival. ${ }^{48}$

The right to water has also been recognised in other international instruments. Article 14 of the Convention for the Elimination of All forms of Discrimination Against Women recognises that women have the right to enjoy adequate living conditions particularly in relation to water supply. Article 24 in paragraph 2 of the Convention for the Rights of the Child also places a positive obligation on states to combat disease and malnutrition through the provision of adequate nutritious foods and clean drinking water. Additionally, Article 28 paragraph 2 of the Convention on the Rights of Persons with Disabilities requires that persons with disabilities have an adequate standard of living and social protection, which includes an obligation on the state to ensure equal access by persons with disabilities to clean water services. It is worth noting that due to the nature of these conventions, they only apply to specific segments of the population. This underscores the importance of General Comment No. 15, which covers all persons.

In 2010, the United Nations General Assembly declared safe and clean drinking water and sanitation a human right under international law $^{49}$ by adopting a Resolution

46 Wekesa (2013: 3). While General Comments are not binding they do have persuasive authority and give states guidance as to the normative content of the rights enshrined in relevant instruments. See Blake (2008). 
on the Human Right to Water and Sanitation. Water and sanitation were thus recognised as a singular, composite, independent right obliging states to ensure the provision of water and sanitation. The Resolution recognises both water and sanitation as a human right essential for the full enjoyment of life and all human rights and calls upon states to provide resources to scale up efforts to provide safe, clean, accessible and affordable drinking water and sanitation for all.

General Comment No. 15 elaborates the normative content of the right to water noting that it must be adequate for human dignity, life and health. ${ }^{50}$ Adequacy, the Committee notes should not be interpreted narrowly and further, water should be treated as a social and cultural good and not primarily as an economic good. ${ }^{51}$ The Committee further notes that while adequacy of water may vary as dictated by circumstances, water must be available, accessible and meet a certain quality (that is, be safe) in all circumstances..$^{52}$

What is noteworthy in contextualising the right to water and sanitation internationally, is that the UN Resolution makes reference to clean and safe drinking water while General Comment No. 15 is broader. The latter provides that this right applies to personal and domestic use which includes drinking, personal sanitation, washing clothes, food preparation, personal and household hygiene. ${ }^{53}$ This is a much broader scope of what the right to water entails than what the General Assembly committed to in 2010.

\subsection{The African human rights system}

The African Charter on Human and Peoples' Rights (the Charter) makes no mention of the right to water in the way other international instruments do. The African Charter on the Rights and Welfare of the Child (Child's Charter), however, recognises that state parties have an obligation to provide safe drinking water for children. ${ }^{54}$ This is not a stand-alone right but a component of the child's right to health as guaranteed in Article 14 of the Child's Charter. While the right to water is included in this Charter, its ambit is limited in that it only guarantees safe drinking water (does not recognise other water needs) for children and only within the context of their right to health. Similarly, the African Protocol on Rights of Women in Africa (Maputo Protocol), through Article 15, recognises the state's obligation to provide women with access to

50 CESCR (2003: para. 11).

51 Ibid.

52 Ibid: para. 12.

53 Ibid: para. 11.

54 Article 14(2)(c) of the African Charter on the Rights and Welfare of the Child. 
clean drinking water as a component of women's rights to nutrition and adequate food. ${ }^{55}$

The human right to water has been recognised in the African human rights system primarily due to the judicial innovation of the African Commission on Human and Peoples' Rights (The Commission). ${ }^{56}$ The Commission has 'read in' the right to water by purposively interpreting the scope of other rights and including water as a subset of these rights. In Free Legal Assistance Group and Others v. Zaire, ${ }^{57}$ the Commission found that the State's failure to provide safe drinking water constituted a violation of the right to health. Similarly, and more expansively, in the landmark case of Social and Economic Rights Action Centre (SERAC) \& Another v. Nigeria,${ }^{58}$ the Commission held that the contamination of sources of drinking water was a violation of the right to health and the right to a satisfactory environment as guaranteed in the Charter.

Until 2015, the Commission treated the right to water as an auxiliary right subject to the protection of more explicit rights, being hesitant to explicitly recognise water as a right and shying away when invited to do so. ${ }^{59}$ Thus while water was not recognised as an independent right in the African human rights system, the Commission has taken cognisance of the fact that rights such as health, housing and dignity cannot be realised without adequate access to water.$^{60}$ However, in 2015, the Commission adopted a resolution on the Right to Water Obligations, which urges member states to meet their obligations to provide clean drinking water for all their populations. ${ }^{61}$ The resolution makes reference to a number of obligations on states including the obligation to guarantee the justiciability of the right to water and to build the capacity of populations in human rights education including the right to water. However, while this Resolution shows the development of the right to water, it does fall short of recognising water as an independent right.

55 See Hellum et al. (2015: 32) for a robust discussion of the recognition of the right to water in the Maputo Protocol and CEDAW.

56 Bulto (2017: 344).

57 ACHPR: Free Legal Assistance Group and Others v. Zaire 4 April 1996 ACHPR 25/89-47/9056/91-100/93 para. 47.

58 ACHPR: Free Legal Assistance Group and Others v. Zaire 4 April 1996 ACHPR 25/89-47/9056/91-100/93 paras 49, 50-54, 57 \& 66.

59 In ACHPR: Sudan Human Rights Organisation \& Another v. Sudan 27 May 2009 279/03296/05 despite an emphatic request that the Commission recognises the independent right to water, it failed to do so without reasons.

60 Bulto (2017: 344).

61 ACHPR Resolution 300 (EST.OS/XVII) of 25 February 2015. 


\subsection{The Kenyan framework for the right to water}

Article 2(6) of the Constitution of Kenya (2010) provides that any treaty or convention ratified by Kenya shall form part of the law of Kenya. Kenya has acceded to the ICESCR, ${ }^{62}$ the Convention of the Elimination of all Forms of Discrimination Against Women, ${ }^{63}$ the Convention for the Rights of the Child ${ }^{64}$ and the Convention on the Rights of Persons with Disabilities. ${ }^{65}$ The provisions combined in these instruments form part of Kenyan law.

Article 43(1) of the Constitution of Kenya (2010) provides that "every person has the right to clean and safe water in adequate quantities". This is understood within the context of the state's obligation to respect, protect, promote and fulfil the rights enshrined in the Bill of Rights. ${ }^{66}$ Further, there is an obligation imposed on the state to take legislative, policy and other measures, including the setting of standards, to achieve the progressive realisation of the right to water. ${ }^{67}$ The state has both negative and positive obligations to ensure that the right to water is realised. The state is at the very least required to desist from preventing and impairing the right to water while positively, the state is required to provide a legislative and policy framework for the right, achieve the progressive realisation of the right and do so within available resources. ${ }^{68}$

The obligation to fulfil the right to water requires that appropriate legislative, administrative, budgetary, judicial and other measures be undertaken to ensure the full realisation of the right. ${ }^{69}$ The Kenya National Commission on Human Rights (KNCHR) has pointed out measures necessary for the realisation of the right to water in Kenya. It recommends the adoption of a national water policy that prioritises water management for essential personal and domestic use; identifies resources available to meet the obligation to fulfil the right to water; specifies cost-effective ways to use the resources; and outlines the responsibilities and timeframes for the realisation of this right. ${ }^{70}$ Essentially, the KNCHR advocates for a rights-based approach to water that prioritises domestic use and avails resources necessary for the realisation of this right in an equitable, non-discriminatory and inclusive manner. ${ }^{71}$

62 Acceded to on 1 May 1972

63 Acceded to on 9 March 1984.

64 Ratified on 30 July 1990.

65 Ratified on 18 May 2008.

66 Article 21(1) of the Constitution of Kenya (2010).

67 Article 21(2) of the Constitution of Kenya (2010).

68 Wekesa (2013).

69 Kenya National Commission on Human Rights (2017).

70 Ibid

71 Ibid. 


\subsubsection{Normative context of Article 43(1)(d)}

Three issues are primarily underscored in Article 43(1)(d) which guarantees the right to water. Firstly, everyone has the right to "clean and safe water", which refers to the quality of water provided. General Comment No. 15 can serve as guidance in this regard as it states that water must be free from microorganisms, chemical substances and radiological hazards that constitute a threat to a person's health. ${ }^{72}$ However, it does remain a matter of legislative or policy directive for the state to determine what clean and safe water means in the context of Kenya. It may be sufficient for the state to adopt international standards but this is a question that is commonly determined in legal systems by balancing exposure-based health assessments with economic cost-benefit analyses. $^{73}$

Secondly, Article 43(1)(d) makes reference to water in adequate quantities. This, of course, begs the question of what would constitute adequate quantities of water. General Comment No. 15 makes reference to the World Health Organisation Guidelines on "Domestic water quantity, service level and health: what should be the goal for water and health sectors", which provide for minimum water requirements but allows for flexibility. The Committee insists that states do not interpret adequacy narrowly with reference to volumetric quantities, but also to consider the social and cultural context of water. Additionally, the Kenya National Commission on Human Rights discusses adequacy and notes that this connotes: ${ }^{74}$

... continuous supply of an amount sufficient for drinking, food preparation, personal and household hygiene and washing. Basic access is defined as 20 litres per person per day, while 50-100 litres per person per day is needed to maintain a basic level of health 7.5 litres per person per day will provide sufficient water for survival needs.

Thirdly, and inevitably, for the right to water to be realised it must be both accessible and available. Availability refers to a continuous and sufficient water supply for personal and domestic use. ${ }^{75}$ Accessibility requires that water, water facilities and services are accessible to everyone without discrimination. ${ }^{76}$ According to the Committee, accessibility has four overlapping dimensions: physical accessibility; economic accessibility; non-discrimination; and information accessibility. ${ }^{77}$ 


\subsubsection{Progressive realisation}

Article 21(2) of the Constitution of Kenya (2010) states that the state shall take legislative, policy and other measures, including the setting of standards, to achieve the progressive realisation of the rights guaranteed under Article 43. What is progressive realisation? How does one define it? How is it quantified? How can citizens hold the state accountable?

The Committee, in General Comment No. 3: The Nature of the State Parties' Obligations, unpacks this term as follows: ${ }^{78}$

The concept of progressive realization constitutes a recognition of the fact that full realization of all economic, social and cultural rights will generally not be able to be achieved in a short period of time... Nevertheless, the fact that realization over time, or in other words progressively, is foreseen under the Covenant should not be misinterpreted as depriving the obligation of all meaningful content. It is on the one hand a necessary flexibility device, reflecting the realities of the real world and the difficulties involved for any country in ensuring full realization of economic, social and cultural rights. On the other hand, the phrase must be read in the light of the overall objective, indeed the raison d'etre, of the Covenant, which is to establish clear obligations for States parties in respect of the full realization of the rights in question. It thus imposes an obligation to move as expeditiously and effectively as possible towards that goal. Moreover, any deliberately retrogressive measures in that regard would require the most careful consideration and would need to be fully justified by reference to the totality of the rights provided for in the Covenant and in the context of the full use of the maximum available.

In Mitubell Welfare Society v. The Attorney General \& 2 Others $^{79}$ the court held that:

The argument that socio-economic rights cannot be claimed at this point two years after the promulgation of the Constitution ignores the fact that no provisions of the Constitution is intended to wait until the state feels it is ready to meet its constitutional obligations. Article 21 and 43 require that there should be "progressive realization" of socio-economic rights, implying that the state must be seen to be taking steps, and I must add be seen to take steps towards realization of these rights.

The Constitution of Kenya (2010) recognises that with limited resources some rights may not be immediately achieved in their entirety. However, that should not be interpreted in a manner that leads to the deprivation of the right. This has been recognised by the CESCR and the High Court of Kenya. The challenge does not lie in understanding that the steps must be taken; it lies in quantifying whether or not the steps taken are adequate. The Constitution of Kenya (2010) goes a step further in Article 20(5)(a) providing that:

In applying any right under Article 43, if the State claims that it does not have the resources to implement the right, a court, tribunal or other authority shall be guided by the following principles - it is the responsibility of the State to show that the resources are not available.

Therefore, the burden of proof is on the state to provide evidence that resources are not available to provide adequate quantities of clean and safe water. A measure of

79 High Court of Kenya Mitubell Welfare Society v. The Attorney General \& 2 Others Petition No. 164 of 2011. 
progressive realisation was noted by the Constitutional Court of South Africa in Mazibuko and Others v. the City of Johannesburg and Others ${ }^{80}$ which held that this concept recognises that "policies formulated by the State will have to be reviewed and revised to ensure that social economic rights are progressively being achieved". While this may serve as a meaningful marker, the Constitutional Court did not go further to explore what the revisions entail and if such revisions translated to increased access to water. Thus, a more meaningful interrogation of both the continued revision of policy and legislation and the increased access to water within the resources available may result in a more meaningful assessment of steps taken by the state.

\subsubsection{Jurisprudence on the right to water}

Since the Constitution of Kenya (2010) was promulgated, two significant cases on the right to water have been adjudicated on. In seeking to contextualise these cases, it must be noted that both cases were founded on evictions and thus a number of violations alleged primarily related to the right to accessible and adequate housing. ${ }^{81}$

The first case is that of Ibrahim Sangor Osman v. Minister of State for Provincial Administration and State Security ${ }^{82}$ where government officials evicted 1,123 persons from their land to make way for constructing a road. The petitioners had occupied the land since the 1940s and were forcefully evicted without notice through a violent process using tear gas and bulldozers. The petitioners were rendered homeless and forced to live in makeshift structures or in the open, and thus were exposed to the elements of nature, health risks and could not access basic necessities like food, water and sanitation. Another result was that several children were forced to drop out of school and elderly members of the community endured unbearable conditions.

The court in coming to its conclusion relied on ICESCR, the Universal Declaration on Human Rights and the International Covenant on Civil and Political Rights. The court found that the purpose of recognising and protecting rights and fundamental freedoms is to preserve the dignity of individuals and communities. ${ }^{83}$ Furthermore, the court in reference to the women, children and elderly persons affected by the eviction, found that the state had an obligation to address the needs of vulnerable persons in the society. ${ }^{84}$ The court found that the fundamental rights of the petitioners had been violated, including the right to water.

80 Constitutional Court of South Africa Mazibuko and Others v. the City of Johannesburg and Others 2010 (4) SA 1 (CC).

81 This is guaranteed in Article 43(1)(b) of the Constitution of Kenya (2010).

82 High Court of Kenya Ibrahim Sangor Osman v. Minister of State for Provincial Administration and State Security Petition No. 2 of 2011.

83 Ibid: 7.

84 Ibid: 11. 
While this court found a violation of the right to water, this was an inevitable consequence of finding that the right to access adequate housing had been violated by the brutal eviction and displacement of an entire community. The court did not meaningfully dissect the right to water, but the decision has jurisprudential value in establishing the inextricable link between the right to water and other rights including housing, health and food.

The second case discussed, Satrose Ayuma \& 11 Others v. The Registered Trustees of the Kenya Railways Staff Retirement Benefits Scheme (the Muthurwa case) ${ }^{85}$ is more significant for its deliberation than for its finding. While the court found that the right to water was not violated, it provided an incisive discussion on the right to water in similar circumstances, namely where petitioners had been evicted from their homes.

Justice Lenaola looked at the normative context of the right to water and considered General Comment No. 15 and rulings from the African Commission on Human and Peoples' Rights that found that state failure to provide basic services such as drinking water constituted a violation of the right to the highest attainable standard of health. ${ }^{86}$ Justice Lenaola recognised that Kenyans are in a fortunate position because the right to water is recognised in the Constitution of Kenya (2010), thereby avoiding the gaps in the international normative framework are avoided.$^{87} \mathrm{He}$ did, however, note that the mere recognition of the right is not sufficient to ameliorate the plight of those without access to water. ${ }^{88}$

Justice Lenaola's rather grim view on the violation of this right is explained in the judgment as follows: ${ }^{89}$

...all Kenyan Municipalities are obliged to manage and operate water services on business and corporate lines and must embrace the full cost of recovery in the provision of water services. The Nairobi Water and Sewage company falls under this category and it is supposed to operate the provisions of water as a business and it ought to make profits, such that the failure of the Petitioners and other persons to pay for the water they have consumed to the tune of Kshs.13 Million necessarily called for disconnection. I will say something about the water bill later in this Judgment but the water supply system as I understand it, demands for payment of a fee to access water. The Petitioners cannot fail to pay for that supply and now be heard to complain about their denial of water when somehow they accepted for the years that they have been tenants that it is their contractual obligation to pay for consumption of water.

85 High Court of Kenya Satrose Ayuma \& 11 Others v. The Registered Trustees of the Kenya Railways Staff Retirement Benefits Scheme Petition No. 65 of 2010. See also East African Centre for Human Rights (undated 8-9 and 33-34) on the horizontal application of the Bill of Rights and for an analysis of the Muthurwa case.

86 ACHPR Free Legal Assistance Group and Others v. Zaire 4 April 1996 ACHPR 25/89-47/9056/91-100/93; ACHPR: Sudan Human Rights Organisation \& Another v. Sudan 27 May 2009 279/03-296/05; and ACHPR: Minority Rights and Minority Rights Group International (on Behalf of Endorois Welfare Council) v. Kenya 25 November 2009 276/03.

87 High Court of Kenya Satrose Ayuma \& 11 Others v. The Registered Trustees of the Kenya Railways Staff Retirement Benefits Scheme Petition No. 65 of 2010 para. 96.

88 Ibid: para. 97.

89 Ibid: para. 100. 
The court concluded that the existing legislative framework was problematic as it had commercialised the provision of water services, required payment for water services and allowed for disconnection from the piped water system where payment was not made. Justice Lenaola, however, went further and held that: ${ }^{90}$

Suffice it to say in any event that it is time the water suppliers and the State adopts a rights based approach with regard to the provision of water services and I suggest that we should borrow a leaf from the South African water laws regime. Section 4(3)(c) of South Africa's Water Services Act states that procedures for the discontinuation of water services must not result in a person being denied access to basic water services for non-payment, where that person proves that he or she is unable to pay for such basic services. Section 4(3) of the Water Services Act further provides that procedures for the limitation or discontinuation of water must be fair and equitable and should provide for reasonable notice of intention to terminate water services and most significantly, for an opportunity to make representations. This, in my view, is what a progressive and realistic realization of social economic rights including the right to water should be.

I must add that it is time that the Kenyan Water Act is amended as it was enacted 8 years before the promulgation of the Constitution, 2010 and it does not expressly provide for the right to water and there is a clear need to have it amended and brought into conformity with the present realities which include the new constitutional dispensation and the devolution of services including the provision of water by County Governments.

This critique is insightful as it provides the executive with directive steps that may be taken towards progressively realising of the right to water, particularly maintaining the provision of access to basic services for persons who are unable to pay for such services. This is a lesson from the South African context and while it is accepted that the judiciary cannot give the executive or legislature direction on policy, this may guide what progressive realisation would mean.

While the court critiqued the situation with regard to the provision of water services, it is disappointing that the court did not make a finding on the violation of the right. This is because firstly, a violation was not found and therefore the court's dictum is merely persuasive and not binding. Secondly, and perhaps more significantly, is the fact that the Constitution of Kenya (2010) had already been promulgated and a normative framework was available at the regional and international levels, yet the primary factor considered in making a determination was the economic value of water (illustrated by the ability to pay for services). The judgment explained its finding as based on the fact that the legislative framework favoured commercialisation. However, it remains a hard pill to swallow considering the right to water is enshrined in the Constitution of Kenya (2010) and the legislation relied on was pre-constitutional. 
One of the more ardent advocates against privatisation of water is Vandana Shiva and in her book, Water Wars: Privatisation, Pollution and Profits, ${ }^{91}$ she lists nine principles underpinning water democracy. These principles are significant for understanding water and its privatisation: water is nature's gift; water is essential to life; life is interconnected through water; water must be free for sustenance needs; water is limited and can be exhausted; water must be conserved; water is a commons; no one holds a right to destroy, and water cannot be substituted.

Significant reasons for the recognition of water as a human right are highlighted it is essential to life and a source of life for all species not just humans. Shiva's criticisms of privatisation are founded on the belief that commodification of water has and shall continue to lead to conflict. ${ }^{92}$ She quotes Ismail Serageldin, vice president of the World Bank: "if wars of this century were fought over oil, the wars in the next century will be fought over water". ${ }^{93}$ Shiva argues that commodification: is non-democratic and centralises the control over decision making and resources; destroys natural resources and erodes the democratic control of natural resources, means of production undermine the cultural identity; and erodes the democratic base of politics because these are hijacked by the World Bank, International Monetary Fund and other players that push the privatisation agenda. ${ }^{94}$

The privatisation of water services has not been coherent in Kenya and prior to 2002, there was no clear legislative framework for the privatisation of water services. However, as noted above, this is not an indication that the water supply was not privatised. Small-scale water vendors, including kiosks and pushcart vendors, have been providing water services outside of the realm of regulation with the implication that neither price nor quality is regulated. This is of course necessitated by the low water supply coverage, which creates a gap in the provision of services and places people at the mercy of vendors.

Certain criticisms were raised at the onset of systematic privatisation of water in Kenya through the Water Act (2002). While privatisation had been pushed as the only option to address public sector mismanagement, there are other options available for reform in the water sector. ${ }^{95} \mathrm{~K}$ 'Akumu argued that privatisation does not necessarily

91 Shiva (2002).

92 Ibid: 7. She notes that water wars are not a thing of the future but they already surround us although they are not always recognised as water wars.

93 Ibid.

94 Ibid: 9.

95 Renzetti \& Dupont (2003: 19) note that empirical data does not unambiguously support the notion that privatisation leads to improved performance. See also studies conducted in the United States of America where there was no difference in performance between privately owned or public enterprises or where public enterprises performed better: Byrnes et al. (1986: 337); Lambert et al. (1993: 1573); and Bhattacharyya et al. (1994: 197). 
provide an advantage over public enterprise and is not a precondition for efficient management. ${ }^{96}$ Many experiences with water privatisation in low and middle-income countries have proved to be disappointing, particularly with regard to extending coverage to lower-income groups.$^{97} \mathrm{He}$ further argued that privatisation had failed to attract private capital, reduce corruption and protect the interests of the poor. ${ }^{98}$

The negative effects of privatisation of water have been experienced in a number of countries such as Chile, ${ }^{99}$ South Africa, ${ }^{100}$ Australia, ${ }^{101}$ Britain $^{102}$ and Argentina ${ }^{103}$. While the drive for privatisation of water in abovementioned countries has been systematic, initiated by the International Monetary Fund and World Bank, ${ }^{104}$ privatisation of water supply in Kenya has been both systematic and unsystematic. In instances of unsystematic privatisation, this gap has led to a sort of entrepreneurship, which can also be described as exploitation. The overall effects of privatisation have, however, been the same as in the countries listed above and include high costs and reduced quality of water supplied.

Legislation including the Water Act (2016) recognises that water belongs to the state and is to be managed and supplied for the benefit of the people, which is a step in the right direction with regard to equity. However, the negative incidences of privatisation discussed above point to the contrary. In Kenya, privatisation does not benefit the marginalised and vulnerable groups.

Another argument against privatisation is that it shifts the state obligation for the fulfilment of a human right for its citizens to private actors, and also directly violates some basic principles particularly those that provide that water must be free for sustenance needs and that water is a common pool resource. There is a counter to this, which notes that this shift does not negate the nature of the human right because the state still has an obligation to develop a system of equity and justice to ensure that such rights are not violated. ${ }^{105}$ Further, it has been contended that the recognition of water as a human right does not necessarily imply that the public sector has to be the provider of these services. ${ }^{106}$ This leads to the following question: does the system for the provision of water in Kenya ensure that the right to water is not violated? The history of

96 K'Akumu (2004: 217).

97 Ibid.

98 Ibid.

99 In Chile, Suz de Lyonnaise insisted on a 35\% profit for supplying water, Shiva (2002: 100).

100 In South Africa, Johannesburg's water supply was overtaken by Suez Lyonnaise des Eaux. Water soon became unsafe, inaccessible, and unaffordable. Thousands of people were disconnected and cholera infections became rampant. See Shiva (2002: 100-101).

101 Hrudey \& Hrudey (2004).

102 In Britain, water and sewage bills increased 67\% between 1989-90 and 1994-95. The rate at which people's services were disconnected rose by $177 \%$. See Shiva (2002: 101).

103 Hacher (2004).

104 Ibid.

105 K'Akumu (2006: 540).

106 Budds \& McGranahan (2003: 94-95). 
privatisation discussed above is illustrative of an incoherent system that has failed to meaningfully consider not only the needs but the views of citizens. The drive for privatisation was mostly a reaction either to state failure to provide services or donor pressure, and thus any argument of justice and equity may be nullified by a process driven outside of the will of citizens.

A further concern is the opaque nature of the terms commercial basis and commercial viability, as used in the Water Act (2002) and the Water Act (2016). It is accepted that there are costs associated with the provision of water services. However, what remains unclear is what it means to be commercially viable and what profit margins are allowed? To what extent is water provided simply as a commodity and not a right? There is not much literature on the licensing practices of the Water Services Regulatory Board and thus it is not clear to what extent economic, commercial and other factors are considered relevant.

Significantly, what the private sector takes to be a commercially viable opportunity may differ from the criteria a state would employ when providing a public service. ${ }^{107}$ The former may have very little to do with developmental goals for the country or a human rights-based approach to the provision of services. ${ }^{108}$ Private service providers are likely to be guided by their investors and market conditions and it remains to be seen whether these guiding factors can translate into the realisation of a human right to water or the implementation of a rights-based approach.

It is encouraging that both the Water Act (2002) and the Water Act (2016) have tariff controls and the Water Services Regulatory Board provides Tariff Guidelines. However, these only seek to regulate water as a commodity. The other factors discussed in terms of adequacy by the CESCR; such as water being treated as a social and cultural good, are not apparent in the legislative framework. ${ }^{109}$ Further, non-discrimination and information availability in the water services' sector are not canvassed in the legislative framework and in practice. The Water Act (2016) has made provision for addressing marginalisation and historical injustices, but there are no explicit requirements for non-discrimination in the provision of water services.

There is a constitutional responsibility to ensure that residents have access to safe and adequate water. Firstly, Kenya needs to address the regulatory lacuna in the cities by prescribing clear standards for water supply and guidelines on allowable amounts to be charged by small-scale water services providers. Secondly, the principles of free

108 Ibid.

109 See $<$ https://wasreb.go.ke/downloads/Tariff\%20guidelines.pdf $>$ (accessed 16-12-2017). 
market cannot apply to the supply of water, because water is necessary for life. Where a model of privatisation is adopted, due consideration to democratic principles of transparency, accountability and public participation must be advanced to allow communities to have a voice in water service provision. Kenya's target is to ensure that every person has access to improved water and sanitation services by 2030. For this to be realised, some hard truths on the intended and unintended consequences of privatisation and commodification have to be honestly addressed before deciding that privatisation is indeed the ideal model for the delivery of human rights.

Water is a human right and water is life. The significance of water to the continuation and development of life on earth, not just human life, cannot be underscored. However, like all other basic needs, there are cost implications in the provision of water services and these costs must be offset. However, meeting costs and making a profit are two separate concepts and privatisation and commodification, as has been discussed in this chapter, are geared towards making profit and not merely meeting the cost of service provision. This raises both moral and legal questions around the commodification of basic human rights. Is it right? Does the state maintain its obligation? To what extent can private actors be held accountable for the provision of human rights? These and many other questions must be answered, as privatisation becomes a model of choice for the provision of services.

The Constitution of Kenya (2010) provides for devolved government in Chapter 11. County governments, in order to accommodate both cultural and societal diversity associated with the use of water, can play a significant role. The framework for the transfer of water services provided to county governments is provided for under the Water Act (2016). There is a need to define commercial viability and allow county governments to develop context-specific standards of commercial viability. There is no applicable one size fits all set of standards for all counties. Similarly, tariffs should not be set nationally, but rather counties should be allowed to determine tariffs in accordance with the needs and affordability level of their constituents.

The concept of social tariffication suggested by K'Akumu, where tariffs are determined on a social rather than commercial basis, remains significant. It would ensure that low-income or poor households connected to the main water network but who cannot afford the market price have tariffs designed to alleviate this difficulty. ${ }^{110}$ K'Akumu suggested that the social tariff be set for the first block of consumption (referring to basic needs) with the cost increasingly progressively with movement up the consumption blocks. ${ }^{111}$ This can also be used as a conservation method because households may limit themselves to their basic needs to minimise their cost. ${ }^{112}$

110 K'Akumu (2004: 220).

111 Ibid.

112 Ibid. 
In line with the above thinking and Justice Lenaola's decision in the Muthurwa case, Kenya should adopt the approach in South Africa's Water Services Act (108 of 1997) that provides that discontinuation of services shall not result in a person losing access to basic services for nonpayment where such a person can prove they are unable to pay for such basic services. ${ }^{113}$ As already noted, water is life and therefore if one cannot afford to pay for it, that alone should not be a reason for denying the right to it. Kenya should include a similar provision in its legislation to protect the most vulnerable persons' rights to water irrespective of their economic status.

The government should develop stop-gap measures to address unintended consequences of privatisation and predatory practices of unregulated water service providers. Literature has shown that it is the poor and marginalised persons, particularly in peri-urban settlements, that fall prey to these practices and a significant portion of their income is used towards accessing a human right. ${ }^{114}$ These stop-gap measures can be put in place while the Water Services Boards work toward increasing coverage and connecting more residents to piped water. Regulations should be developed to address unlicensed water service providers and a framework put in place for the Water Services Regulatory Board, to manage the quality and price of the services provided.

\section{References}

Bhattacharyya, A, E Parker \& K Raffiee (1994) "An examination of the effect of ownership on the relative efficiency of public and private water utilities" 70(2) Land Economics 197-209.

Blake, C (2008) Normative instruments on international human rights law: locating the general comment Centre for Human Rights and Global Justice Working Paper No. 17.

Byrnes, P, S Grosskopf \& K Hayes (1986) "Efficiency and ownership: further evidence" 68(2) Review of Economics and Statistics 337-341.

Budds, J \& G McGranahan (2003) "Are the debates on water privatization missing the point? Experiences from Africa, Asia and Latin America” 15(2) Environment \& Urbanization 87-114.

Bulto, TS (2017) "The human right to water in the corpus and jurisprudence of the African human rights system" 11(2) African Human Rights Law Journal 341-367.

CESCR / International Covenant on Economic, Social and Cultural Rights (1990) General Comment No. 3: The Nature of State Parties' Obligations (Article 2, Para 1, of the Covenant), at $<$ http://www.refworld.org/pdfid/4538838e10.pdf > (accessed 26-3-2018).

CESCR / International Covenant on Economic, Social and Cultural Rights (2003) General Comment No. 15: the right to water (Articles 11 and 12 of the International Covenant on Economic, Social and Cultural Rights, at <http:/www2.ohchr.org/english/issues/water/docs/CESCR_GC_15.pdf> (accessed 15-12-2017).

113 Section 4(3)(c) of the Water Services Act (1997).

114 UNDP (2011). See also K'Akumu \& Appida (2006: 315); and K'Akumu (2007: 534) on the exclusion of poor and marginalised communities from water services and the inevitable effect of using water services vendors. 
Chuma J \& Okungu V (2011) "Viewing the Kenya health system through and equity lens: implications for universal coverage" (26-05-2011) 10(22) International Journal for Equity in Health, at $<$ https://equityhealthj.biomedcentral.com/articles/10.1186/1475-9276-10-22> (accessed 5-062017).

East African Centre for Human Rights (undated) Compendium on economic and social rights cases under the Constitution of Kenya, 2010, at <http://eachrights.or.ke/wp-content/uploads/2017/12/A_Compendium_On_Economic_And_Social_Rights_Cases_Under_The_Constitution_Of_Kenya_2010.pdf> (accessed 25-5-2018).

Government of Kenya (1965) African socialism and its application to Kenya Sessional Paper No. 10.

Government of Kenya (1979) Fourth national development plan (1979-83).

Government of Kenya (1986) Economic management for renewed growth Sessional Paper No. 1.

Government of Kenya (1992) Delineation study of water and sanitation sector in Kenya.

Government of Kenya (2009) Sector investment plan for the water and sanitation sector in Kenya.

Government of Kenya (2010) Water sector strategic plan (WSSP) 2009-2014.

Gupta, J, R Ahlers \& L Ahmed (2010) "The human right to water: moving towards consensus in a fragmented world" 19(3) Review of European Community \& International Environmental Law 294-305.

Hacher, S (2004) "Argentina water privatization scheme runs dry" Corpwatch (26-2-2004), at $<$ http://www.corpwatch.org/article/argentina-water-privatization-scheme-runs-dry $>$ (accessed 1111-2017).

Hellum, A, I Ikdahl \& P Kameri-Mbote (2015) "Turning the tide: engendering the human right to water and sanitation" in A Hellum, P Kameri-Mbote \& B van Koppen (eds) Water is life: women's human rights in national and local water governance in southern and eastern Africa 32-80.

Hrudey, EJ \& SE Hrudey (2004) Safe drinking water: lessons from recent outbreaks in affluent nations.

Jaglin, S (2002) "The right to water versus cost of recovery: participation, urban water supply and the poor in sub Saharan Africa” 14(1) Environment \& Urbanization 231-245.

Lambert, D, D Dichey \& K Raffiee (1993) "Ownership and sources of inefficiency in the provision of water services” 29(6) Water Resources Research 1573-1578.

Kameri-Mbote, P \& F Kariuki (2015) "Human rights, gender and water in Kenya: law, prospects and challenges" in A Hellum, P Kameri-Mbote \& B van Koppen (eds) Water is life: women's human rights in national and local water governance in southern and eastern Africa 81-117.

Kenya National Commission on Human Rights (2017) "Framework for monitoring the realization of the rights to water and sanitation in Kenya", at $<$ http://knchr.org/Portals/0/EcosocReports/PHEFramework.pdf?ver=2018-05-16-082038-583> (accessed 25-5-2018).

K'Akumu, OA (2004) "Privatisation of the urban water supply in Kenya: policy options for the poor" 16(2) Environment \& Urbanization 213-222.

K'Akumu, OA (2006) "Privatisation model for water enterprise in Kenya" 8(6) Water Policy 539557.

K'Akumu, OA (2007) "Toward effective governance of water services in Kenya" 9(5) Water Policy 529-543.

K'Akumu, OA \& PO Appida (2006) "Privatisation of urban water service provision: the Kenyan experiment" 8(4) Water Policy 313-324.

Moyo, S \& C Kinuthia-Njenga (1998) Privatisation of municipal services in East Africa: a governance approach to human settlements management. 
Mugo, K (2011) "Partnership working brings safe water to Kenya's poor" The Guardian Sustainable Business (9-8-2011), at https://www.theguardian.com/sustainable-business/revolutionised-kenyawater-supply-business (accessed 11-11-2017).

Mwega, FM (2009) A case study of AID effectiveness in Kenya: volatility and fragmentation of foreign AID, with a focus on health Wolfensohn Centre for Development Working Paper No. 8, at $<$ https://www.brookings.edu/wp-content/uploads/2016/06/01_kenya_aid_mwega.pdf $>$ (accessed 29-5-2018).

Notley, J, C Gathuthi, J Murage, B Junker \& C Katee (2010) Lessons learned and good practices from support to the Kenyan water sector, at $<\mathrm{https}$ ://www.ircwash.org/sites/default/files/Notley2010-Lessons.pdf> (accessed 17-12-2017).

Ogendi, GM \& IM Ong’oa (2009) "Water policy, accessibility and water ethics in Kenya” (7)1 Santa Clara Journal of International Law 177-196.

Renzetti, S \& D Dupont D (2003) "Ownership and performance of water utilities" 42 Greener Management International 9-19.

Shiva, V (2002) Water wars: privatization, pollution, and profit.

Shurie, M, B Mwaniki \& P Kameri-Mbote (2017) Project country report: water permit systems, policy reforms and implications for equity in Kenya, at $<\mathrm{http}$ //africa.iwmi.cgiar.org/wp-content/uploads/sites/2/2017/04/Water-Permitting-Kenya-Country-Report-PI_IWMI-March-2017.pdf> (accessed 17-12-2017).

Swallow, B, NA Okono, C Ong \& F Place (2003) "TransVic: improved land management across the Lake Victoria Basin" in RR Harwood \& AH Kassam (eds) Research towards intergrated natural resources management: examples of research problems, approaches and partnerships in action in the CGIAR 65-78.

Tully, S (2005) "A human right to access water? a critique of general comment No. 15" 23(1) Netherlands Quarterly of Human Rights 35-63.

UNDP / United Nations Development Programme (2011) Small-scale water providers in Kenya: pioneers or predators?

Uwazi InfoShop (undated) "It's our water too! Bringing greater equality in access to water in Kenya", at $<$ http://www.uwazi.org/24D5E300-20A1-40D5-BEE5-6065ECD7D289/FinalDownload/Down loadId9548731E84A4A0092EEA01B8AE31BD64/24D5E300-20A1-40D5-BEE5-6065ECD7D2 89/uploads/files/KE\%20english\%20It\%20is\%20Our\%20Water\%20Too\%20.pdf> (accessed 1111-2017).

Wambua, S (2004) "Water privatization in Kenya" 8 Global Issues Papers 1.

Water and Sanitation Programme (undated) Water supply and sanitation in Kenya: turning finance into services for 2015 and beyond, at <http://wsp.org/sites/wsp.org/files/publications/CSOKenya.pdf $>$ (accessed 25-05-2018).

Wekesa, S (2013) "Right to clean safe water under the Kenyan Constitution 2010" 14(3) Economic and Social Rights Review 3-6.

WHO / World Health Organization (1993) Guidelines for drinking water quality 2nd Ed. 